\title{
Performance of Dredged Sediment as a Replacement for Fine Aggregates in Concrete Mixture: Case Study at Sungai Pekan, Pahang
}

\author{
Norpadzlihatun Manap ${ }^{1, *}$, Gomathi Govindasamy ${ }^{1}$, Sulzakimin Mohamed ${ }^{1}$, Narimah Kasim ${ }^{1}$, Sharifah Meryam Shareh \\ Musa $^{1}$, and Mohd Yamani Yahya ${ }^{1}$ \\ ${ }^{1}$ Department of Construction Management, Faculty of Technology Management and Business, Universiti Tun Hussein Onn Malaysia, \\ 86400 Parit Raja, Batu Pahat, Johor, Malaysia
}

\begin{abstract}
Dredging is essential to maintain suitable depth for shipping by removing dredged sediments from sea and river banks. It is also an important process to supply construction material. In Pahang, increasing flood cases is occurring due to increased sea and river bed level. Thus, dredging is needed to be performed in this location. In addition, the rapid growth of the construction industry requires a sustainable approach. The reuse of dredged sediments as construction material could be a sustainable approach. Therefore, this research aims to study the engineering properties of dredged sediments and to compare the strength of concrete made from dredged sediments with conventional concrete. The samples for this research obtained from the location of this study at Sungai Pekan. Laboratory testing was performed to determine the engineering properties of dredged sediments and compressive strength of concrete produced from the dredged sediments. The highest average compressive strength of the concrete cube produced from Sample 1 is $9.2 \mathrm{~N} / \mathrm{mm}^{2}$ for seven days and $11.9 \mathrm{~N} / \mathrm{mm}^{2}$ for 28 days curing period. Comparatively, Sample 3 has the lowest average compressive strength that is $2.1 \mathrm{~N} / \mathrm{mm}^{2}$ for seven days and $2.7 \mathrm{~N} / \mathrm{mm}^{2}$ for 28 days curing period. The strength that is required to be achieved is $14 \mathrm{~N} / \mathrm{mm}^{2}$ for curing seven days and $20 \mathrm{~N} / \mathrm{mm}^{2}$ for curing period of 28 days. In conclusion, the concrete cubes made from dredged sediment taken at the sampling area are unable to produce concrete that satisfies the minimum strength for the $\mathrm{C} 20$ concrete mix. Therefore, it can be concluded that there is the minimal potential use of dredged sediments taken from the location of this study for the production of concrete in the construction industry.
\end{abstract}

\section{Introduction}

Concrete has been the popular construction material used since the past till now. It widely used than any other materials in the construction industry. It is due to the advantages such as low cost, availability, and strength compared to wood or timber.

Concrete generally composed of aggregates, cement and water and sometimes admixtures to increase its' strength and properties which is required for construction purposes. The types of aggregates used are coarse and fine aggregates. The coarse aggregates' particles sizes are bigger than $5 \mathrm{~mm}$ in diameter while fine aggregates' will be smaller than $5 \mathrm{~mm}$ in diameter [1].

Excellent quality of concrete produced by careful mixing of cement, fine, coarse aggregates, water, and admixtures as needed to obtain an optimum quality [17]. Generally, the production of cement and coarse aggregates will be made in the factory. Therefore, their quality and standards can be easily controlled and maintained. Water used for mixing of concrete is usually tap water. Whereas, the fine aggregates or sand obtained from natural sources like sea banks or river banks [2].

Dredging can be defined as a process of extraction of sediments from the bottom of waterways in order to enhance the water flow or to make profitable use of those dredged sediments. Although dredging activity is needed for the development of a country, there are many environmental effects resulted both in the short term or long term $[3,4]$.

The Port Authority of New York dredged about millions of cubic yards each year to keep the shipping lanes open and also to deepen them in order to accommodate larger vessels. As long as the disposal in the open ocean was done, the cost incurred was minimal until national legislation claimed that those disposed of dredged sediments are harmful to the environment due to its' high contamination level. Thus, a confined disposal facility needed to be implemented at a high cost. Similar problems are faced by all major world ports as well in Malaysia [16].

Therefore, if an alternative can be derived from the disposed of dredged sediments, then the dumping of those dredged sediments can be decreased as well as the

\footnotetext{
* Corresponding author: padzliha@uthm.edu.my
} 
environmental impacts and the cost involved in disposing of the sediments $[18,19,20]$. Thus, this research will examine the potential use of dredged sediments as substitutes for fine aggregates for the production of concrete in the construction industry. The engineering properties of the dredged sediments will be determined in order to understand its' suitability for the construction industry through several laboratory testing.

In Malaysia, million cubic meters of soils dredged every year. This is due to the continuous demand for maintenance sea or river for shipping purpose. However, the dumping of dredged sediments to the offshore may lead to a severe impact on the ecosystem. Some countries had already made use of these dredged sediments, for example, in Japan, there are more than $90 \%$ of dredged sediments were used [5]. However, in Malaysia, dredged sediments are often being disposed to offshore, thoughtless to reuse them $[6,7,8,9]$.

According to the latest news, on the 8th of March 2015, Pahang plans to deepen and clean up rivers to solve flood woes [10]. This news has given an alert to the public that the water level of the Pahang River is decreasing and the aquaculture activities are unable to continue their activities because of this. This leads to massive loss to the residents and aquaculturists living around the area. Other than that, if there is extreme rainfall, the water level of the river will rise drastically and leads to flooding in Pahang. This is because of the sand blocking at the water intake point of the river [11].

The water level of Pahang River at Pekan for six days monitored from 12th of March 2015 to 17 th of March 2015. The water level of the river shows $2.06 \mathrm{~m}$ on 17th of March 2015 that it is above the average level $1.00 \mathrm{~m}$ of the river [12]. If this case prolongs, then Pahang will face a bigger scale of floods in the near future. Thus, dredging activity is essential in order to clear the waterways which have been blocked due to sedimentation. This will indirectly assist to reduce the increasing water level back to average level.

Furthermore, among the six districts affected by flood in Pahang, Pekan has the most numbers of victims $(11,154$ people) compared to the least in Jerantut (655 people). This shows that Pekan is facing severe irrigation and drainage problems which needed to be taken into consideration by state government [13]. Other than that, referring to the data by Department of Irrigation and Drainage Pahang state shows a gradual increase in the number of flood incident from the Year 2009 to the Year 2013. This fact draws attention towards the necessity of dredging activity to make sustainable use of Pahang River.

Pahang River Mouth Improvement (PRMI) is one of the most significant coastal engineering projects which are being carried out in the country currently. This project aims to solve the problem of siltation at the river mouth which affects the navigation of fishing vessels, to provide adequate navigation channels and to reduce the risk of coastal flooding to Pekan town and surrounding areas [14]. Also, according to data obtained from Malaysian Maritime \& Dredging Corporation (MMDC), there are dredging works which have been carried out for specific purposes at many parts of Peninsular Malaysia, starting from the year 2008 till 2013. This shows that there is a good demand for the necessity of dredging in Malaysia.

Apart from that, in Malaysia, the dredged sediments from these dredging activities are not being utilized whereas they are dumped in an open area due to its contamination level. Less initiative has been taken to treat and use the sediments for other purposes such as in construction industry in Malaysia [11,12]. Therefore, an innovative idea needed to be implemented or proposed in order to avoid the dumping of dredged sediments offshore or in land and indirectly reduce the flood and the environmental effects. Thus, in this research, production of concrete will be done from the dredged sediments collected from the location of this study near Sungai Pekan, Pahang. It is desirable to reuse the disposed of dredged sediments for construction purposes.

This research will aim to study the engineering properties of dredged sediments and to compare the strength of concrete made from dredged sediments with conventional concrete. The samples of this research taken from the location near Sungai Pekan, Pahang. Dredging activity is crucially needed to be done in Sungai Pekan, Pahang to remove the sand blocking in the river. Therefore, the work to dig up sedimentation from the river had been approved by the state government on 19 September 2013 (Phase 3). Thus, it was appropriate to take the sample from the location near Sungai Pekan for this research purpose. Three types of samples collected along the river. They are then labelled as Sample 1, Sample 2 and Sample 3. After the retrieval of the sample, it was used to determine the engineering properties at Soil Mechanics laboratory in the Faculty of Technology Management and Business (FPTP), Universiti Tun Hussein Onn (UTHM), Johor. Later, the tested sediments were used to produce concrete. Finally, the strength of the produced concrete tested in the laboratory of FPTP.

\section{Materials and specimen preparation}

Site investigation is essential in order to determine the suitability of the site for sample collection. The samples for this research that is dredged sediments were collected from Sungai Pekan, Pahang via grab method. There were active dredging activities which have been carried out during the sample collection, and discarded dredged sediments were collected and stored in containers. Three types of samples collected along the river as the texture of the sediments differ from one another. The collected samples stored in a plastic container. Later, the samples brought back to the Soil Mechanics laboratory, FPTP, UTHM where the engineering properties of the sediments and the strength of concrete made from the sediments were tested.

The dredged sediments went through thermal treatment as the water content of those sediments were high. High water content for the production of concrete is not good as it will reduce the strength of the concrete made. Thus, the sediments were placed in a big metal tray then dried inside an oven at $250^{\circ} \mathrm{C}$ for 24 hours. 
Also, thermal treatment induces thermal immobilisation in which causes organic impurities to be broken down at high temperature. This assists the organic content in the sediments to be removed. Besides, it will also reduce the chemical deterioration in the concrete mixture. After it dried for 24 hours, the samples were then crushed into fine particles using a hammer. The engineering properties of dredged sediments tested before the production of concrete. The laboratories testing which was conducted is as Sieve Analysis Test and Determination of Moisture Content. Sieve Analysis Test test was carried out in order to study the grain size of the sediments by passing them through a stack of sieves of decreasing mesh opening sizes and by measuring the weight retained on each sieve. Sieving will also help to remove unwanted objects, such as dried leaves, branches, and stones. These unwanted objects in the mixture of concrete will influence the strength of the concrete cubes produced. BS 882 used as a guideline throughout this test. Determination of Moisture Content covers the laboratory determination of the moisture content of the dredged sediments as a percentage of its oven-dried weight. It is based on removing the dredged sediments moisture by oven-drying the samples until the weight remains constant. The moisture content (\%) calculated from the sample weight before and after drying. BS 1377: Part 2 used as a guideline throughout the test.

The ratio of cement, sand, and aggregate used was $1: 2: 4$, with the dredged sediments used as the substitute for fine aggregates in concrete. The concrete produced was in the grade of $\mathrm{C} 20$ as this is the medium strength concrete which is widely used in construction industry. The water-cement ratio fixed at 0.55 . JKR Standard 2005 used as a guideline during the laboratory testing of concrete production. There were 18 cubes of concrete produced using three samples of dredged sediments from Sungai Pekan, Pahang. There were six batches for each type of sample which stands from 3 batches for 7 days curing period and three batches for 28 days curing period. The standard concrete production procedures used in the production of concrete made from dredged sediments. The only difference will be the substitution of sand that is the fine aggregates for concrete with the dredged sediments. Even though during the mixing of the concrete the water required was slightly higher than the fixed water-cement ratio, the water used to mix the concrete was not added because this will influence the strength of concrete produced. The water-cement ratio and percentage of dredged sediments were kept constant. The concrete was mixed then molded. The size of the mould used was $100 \mathrm{~mm}$ which is the standard size for the concrete cubes. The concrete was then de-molded and kept for curing in the curing tank for seven days and 28days.

The concrete cured for seven days and 28 days. After the curing period, the concrete was taken out from its curing tank and subjected to a compression test. The compressor was used to conduct the compressive strength test of concrete. The compressor provided the readings, and this eliminates the calculation process for the strength of concrete.

\section{Results and discussion}

The fine aggregates in the production of concrete replaced with dredged sediments collected from the location near Sungai Pekan, Pahang which has labelled as Sample 1, Sample 2 and Sample 3. The strength of concrete made from dredged sediments will then compared to the strength conventional concrete under JKR Standard 2005.

\subsection{Particle Size Distribution}

Three samples subjected to particle size distribution examination. Sieve analysis was carried out on the dredged sediment samples to determine their degrees of fineness using the following aperture sizes of $10 \mathrm{~mm}$, $6 \mathrm{~mm}, 1 \mathrm{~mm}, 0.6 \mathrm{~mm}, 0.3 \mathrm{~mm}, 0.15 \mathrm{~mm}$ and $0.063 \mathrm{~mm}$. Percentages of sediment passing and retained were analyzed, and the grading curve plotted. The samples were then graded using the BS sieves. Based on the samples tested, $86 \%$ of the sample passing through sieve size 600 microns for Sample 3. Comparatively, 65\% and $60 \%$ of the sample passing through sieve size 600 microns for Sample 2 and Sample 1. Besides, the color, texture and particle shape of these samples observed during the test. Irregularly shaped particles with smooth and fine texture observed. The colors of the samples were dark brown and black. Irregular and angular sand particles are ordinary in river sands as a result of attrition forces in water [15].

On the other hand, Sample 1 and Sample 2 were graded within Zone III that is fine sand whereas Sample 3 was graded within Zone IV that comprised of very fine sand. These types of fine grading require proper mix design proportion. This shows that the dredged sediments used in this research are comprised of clay and silt respectively.

\subsection{Determination of moisture content}

The moisture content of Sample 3 shows the highest that is $18.13 \%$ compared to the moisture content of Sample 2 and Sample 1 that is $14.81 \%$ and $13.91 \%$. Thus, texture, particle size, and moisture content did affect the strength of the concrete produced from the dredged sediments taken from the location of this case study near Sungai Pekan, Pahang.

\subsection{Compressive strength of concrete}

The results obtained through a compressive strength test conducted using three samples collected from the location near Sungai Pekan, Pahang. The reading from the compressive strength test was taken from each sample using a compressor is to determine the maximum load that can be borne by the concrete made of dredged sediments.

The average strength of concrete taken from 3 concrete cubes made from each sample for a curing period of 7 days and 28 days. Later, the average reading 
of the concrete made of dredged sediments compared to the strength of conventional concrete following JKR standard 2005.

The data which has tabulated from the compressive strength test for each sample for curing seven days and 28 days are shown in Table 5, Table 6, and Table 7 respectively.

Table 1. Compressive Strength of concrete made from Sample

\begin{tabular}{lccc}
\hline Sample 1 & $\begin{array}{c}\text { Maximum } \\
\text { Load } \\
(\mathbf{k N )}\end{array}$ & $\begin{array}{c}\text { Compressive } \\
\text { Strength } \\
\left(\mathbf{N} / \mathbf{m m}^{\mathbf{2}}\right)\end{array}$ & $\begin{array}{c}\text { Curing } \\
\text { Duration } \\
\text { (days) }\end{array}$ \\
\hline Cube 1 & 96.6 & 9.7 & 7 \\
Cube 2 & 83.6 & 8.4 & 7 \\
Cube 3 & 95.8 & 9.6 & 7 \\
Cube 4 & 120.5 & 12.1 & 28 \\
Cube 5 & 116.9 & 11.7 & 28 \\
Cube 6 & 120.4 & 12 & 28 \\
\hline
\end{tabular}

Table 2. Compressive Strength of concrete made from Sample 2

\begin{tabular}{cccc}
\hline Sample 2 & $\begin{array}{c}\text { Maximum } \\
\text { Load } \\
(\mathbf{k N})\end{array}$ & $\begin{array}{c}\text { Compressive } \\
\text { Strength } \\
\left(\mathbf{N} / \mathbf{m m}^{2}\right)\end{array}$ & $\begin{array}{c}\text { Curing } \\
\text { Duration } \\
\text { (days) }\end{array}$ \\
\hline Cube 1 & 72.5 & 7.3 & 7 \\
Cube 2 & 73 & 7.3 & 7 \\
Cube 3 & 75 & 7.5 & 7 \\
Cube 4 & 93.1 & 9.3 & 28 \\
Cube 5 & 97.1 & 9.7 & 28 \\
Cube 6 & 102.9 & 10.3 & 28 \\
\hline
\end{tabular}

Table 3. Compressive Strength of concrete made from Sample 3

\begin{tabular}{cccc}
\hline $\begin{array}{c}\text { Sample } \\
\mathbf{3}\end{array}$ & $\begin{array}{c}\text { Maximum } \\
\text { Load } \\
(\mathbf{k N )}\end{array}$ & $\begin{array}{c}\text { Compressive } \\
\text { Strength } \\
\left(\mathbf{N} / \mathbf{m m}^{2}\right)\end{array}$ & $\begin{array}{c}\text { Curing } \\
\text { Duration } \\
\text { (days) }\end{array}$ \\
\hline Cube 1 & 21.1 & 2.1 & 7 \\
Cube 2 & 20.5 & 2.1 & 7 \\
Cube 3 & 22 & 2.2 & 7 \\
Cube 4 & 27 & 2.7 & 28 \\
Cube 5 & 28 & 2.8 & 28 \\
Cube 6 & 27 & 2.7 & 28 \\
\hline
\end{tabular}

\subsection{Average compressive strength of concrete}

Figure 1 shows the average compressive strength of concrete made of Sample 1, Sample 2 and Sample 3 for the curing period of 7 days and 28 days. The red line in Figure 1 and Figure 2 shows the minimum required strength. According to JKR Standard 2005, the minimum strength required for curing seven days is $14 \mathrm{~N} / \mathrm{mm}^{2}$ and $20 \mathrm{~N} / \mathrm{mm}^{2}$ for 28 days for concrete grade C 20 .

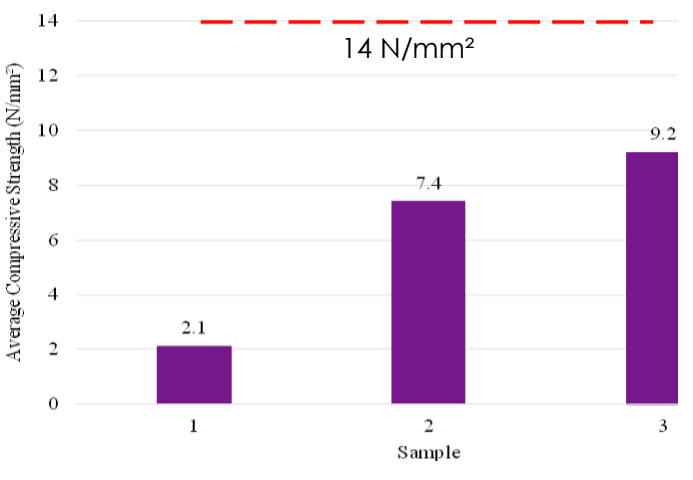

Fig 1 Average compressive strength of concrete for curing seven days

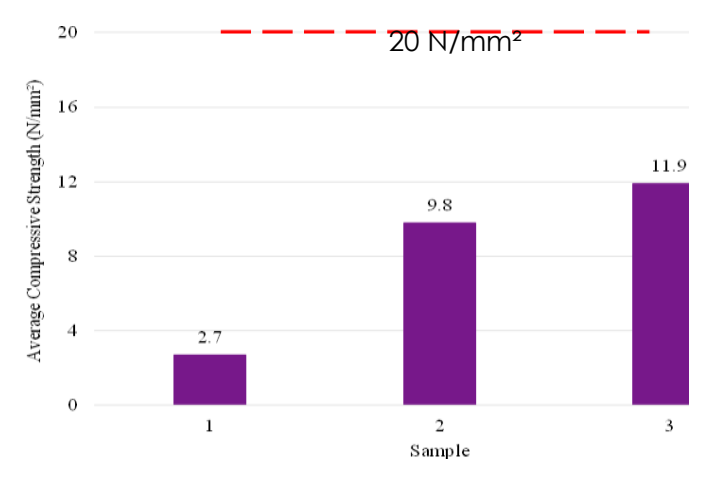

Fig. 2. The average compressive strength of concrete for curing 28 days

From the results, the samples failed to meet the minimum strength required for both seven days and 28 days. Sample 1 shows the highest average compressive strength reading that is $9.2 \mathrm{~N} / \mathrm{mm}^{2}$ for seven days and $11.9 \mathrm{~N} / \mathrm{mm}^{2}$ for 28 days. The concrete shows a difference of $4.8 \mathrm{~N} / \mathrm{mm}^{2}$ and $8.1 \mathrm{~N} / \mathrm{mm}^{2}$ in strength. Comparatively, Sample 3 has the lowest average of compressive strength reading that is $2.1 \mathrm{~N} / \mathrm{mm}^{2}$ when cured for 7 days and $2.7 \mathrm{~N} / \mathrm{mm}^{2}$ when cured for 28 days. The concrete shows a difference of $11.9 \mathrm{~N} / \mathrm{mm}^{2}$ and 17.3 $\mathrm{N} / \mathrm{mm}^{2}$ in strength respectively.

Since all the samples subjected to similar casting and curing conditions, this failure is mostly attributed to the presence of clay and silt content and particle size, shapes, and texture of those dredged sediments. The higher the clay and silt content in the samples portrayed the smallest amount of compressive strength that is $2.1 \mathrm{~N} / \mathrm{mm}^{2}$ (7days) and $2.7 \mathrm{~N} / \mathrm{mm}^{2}$ (28days). Smooth, fine texture and irregularly shaped sample surfaces provide a weak interlocking bond between cement and aggregates [15].

It was observed during sample collection; sample 3 was highly contaminated compared to Sample 1 and Sample 2. To some extent, contamination level can also be one of the factors for the failure of concrete made. The sediment which has been contaminated with oil and presence of organic impurities from the dredger and the surrounding environment can affect the chemical composition between cement and fine aggregates that is dredged sediments in the production of concrete in this 
research and indirectly reduces the strength of the concrete produced.

Besides, a constant water-cement ratio that is 0.55 was used throughout the test. It was observed to obtain the same consistency as conventional concrete; dredged sediments required more water than standard fine aggregates. Since the water-cement ratio was not adjusted, less fluidity concrete cubes were produced.

However, it was observed that the average compressive strength at day 28 has increased compared to average compressive strength at day 7 . This shows the importance of curing days in determining the strength of concrete. Although the compressive strength at day 7 and day 28 failed to meet the minimum required strength, the results show that the strength increases concerning time. Generally, it can be observed that the longer the curing period, the higher the gain of compressive strength.

\section{Conclusion}

The first objective of this research is to study the engineering properties of dredged sediments. The engineering properties which have been carried out in this research are sieve analysis test and consolidation test.

The percentage passing through sieve size $600 \mu \mathrm{m}$ in Sample 1 is $60 \%$, and it has been graded within Zone III that is fine sand. The percentage passing through sieve size $600 \mu \mathrm{m}$ in Sample 2 is $65 \%$, and it has been graded within Zone III as well. Whereas in Sample 3 the percentage passing through sieve size $600 \mu \mathrm{m}$ is $86 \%$, and that falls under Zone IV that is very fine sand. It was observed that the samples were dark brown and black. They have a smooth and fine texture with an irregular shape.

The moisture content of Sample 3 shows the highest that is $18.13 \%$ compared to the moisture content of Sample 2 and Sample 1 that is $14.81 \%$ and $13.91 \%$. Generally, moisture content for dredged sediments is high and could result in a lower strength of soil. Besides, the high water content in concrete production is also not good because it can decrease the strength of the concrete itself. This notion was supported in the research made by [6].

The second objective of this research is to compare the strength of concrete made from dredged sediments with conventional concrete (C20). The strength of concrete made from dredged sediments from Sungai Pekan, Pahang did not meet the minimum required strength by JKR for curing seven days and 28 days respectively.

The highest average compressive strength of the concrete cube produced is from Sample 1 that is 9.2 $\mathrm{N} / \mathrm{mm}^{2}$ for seven days and $11.9 \mathrm{~N} / \mathrm{mm}^{2}$ for 28 days curing period. Comparatively, Sample 3 has the lowest average compressive strength that is $2.1 \mathrm{~N} / \mathrm{mm}^{2}$ for seven days and $2.7 \mathrm{~N} / \mathrm{mm}^{2}$ for 28 days curing period. The strength that is required to be achieved is $14 \mathrm{~N} / \mathrm{mm}^{2}$ for curing period of 7 days and $20 \mathrm{~N} / \mathrm{mm}^{2}$ for curing period of 28 days. It is clear that the dredged sediments from Sungai Pekan, Pahang fail to meet the required standard.

It can be concluded that dredged sediments taken from the location of this study near Sungai Pekan, Pahang is not suitable to be made as fine aggregates in the production of concrete. Treatment method needs to be carried out in order to reduce the contamination level in the dredged sediments before using them in the construction industry. Other than that, water cement ratio should be adjusted accordingly during the mixing of concrete. This is because the higher the amount of silt used in the production of concrete, the more the water required maintaining its consistency as in conventional concrete.

This research was performed to fulfill the requirement of research grant with Vote no. R063. Acknowledgments are given to the Ministry of Higher Education Malaysia and the Office for Research, Innovation, Commercialization and Consultancy Management, Universiti Tun Hussein Onn Malaysia for all their support during the publication of this paper. Acknowledgments are also given to all relevant agencies for the support given during the writing of this paper.

\section{References}

1. G. K. Manguriu. Global Engineers \& Technologists Review. 3(4): 7-14. (2013)

2. N. Vijayaraghavan, \& A. S. Wayal, International Journal of Structural and Civil Engineering Research. 2(4): 229-232. (2013)

3. N. Manap and N. Voulvoulis, Applied Mechanics and Materials, 567, pp. 50-55 (2014)

4. K. Sandirasegaran and N. Manap, Jurnal Teknologi, 73(3): 139-143.(2016)

5. Central Dredging Association (CEDA). A CEDA Information Paper. (2010)

6. A. Azhar, C. M., Chan, A.T. Ab. Advances in Environmental Biology. 1: 94-99. (2014)

7. N. Manap, K.Y. Tan and N. Shahrom, IOP Conference Series: Earth and Environmental Science, 109, 012026 (2017)

8. N. Manap, N. Jeyaramah, and N. Syahrom, IOP Conference Series: Earth and Environmental Science, 109, 012027 (2017)

9. N. Manap, N.I. Muhamad and K. Sandirasegaran, Materials Science Forum, 889 261-264. (2017)

10. Bernama, To Solve Flood Woes, Pahang Plans to Deepen, Clean Up Rivers. (2015) [Online]. Available:

http://www.themalaymailonline.com/malaysia/ article/to-slove-flood-woes-pahang-plans-todeepen-clean-up-rivers\#sthash.IzLNKUYd.dpuf.

11. The Star. River project to cost RM568mil. (2015) [Online]. Available: www.thestar.com.my/Metro/Community/2015/ 
03/20/River-project-to-cost-RM568mil-Fiverivers-in-Pahang-to-be-deepened-andrealigned-to-reduce-damage-d/

12. Department of Drainage (DID). On-Line River Level Data. (2015). [Online]. Available: http://infobanjir.water.gov.my/waterlevel_page .cfm?state=PHG

13. S. Khoo, Floods: Six districts still affected in Pahang. (2015). [Online]. Available: http://www.thestar.com.my/News/Nation/2015 /01/06/Floods-Six-districts-Pahang/.

14. Malaysian Resources Corporation Berhad (MRCB) (2011). [Online]. Available: http://www.mrcbice.com.my/projects_finished_p1_sgpahang.ph p.

15. H. M. Ngugi, Open Journal of Civil Engineering. 4: 255-273, 2014)

16. N. Manap, Y.K. Goh and N. Syahrom, IOP Conference Series: Earth and Environmental Science, 109, 012008, 2017)

17. N. Manap, N.H. Mohd Noh and N. Syahrom, IOP Conference Series: Earth and Environmental Science, 109, 012011, 2017)

18. N. Manap, R.A.A., Raja Bedali, K. Sandirasegaran, M.A.N. Masrom, and M.Y. Yahya, Jurnal Teknologi, 78(3), pp. 87-92, 2016)

19. N. Manap and N. Zulkifli, Journal of Food Agriculture and Environment, 10(1), pp. 10311038, 2012.

20. N. Manap, S. Polis, K. Sandirasegaran, M.A.N. Masrom, K.C. Goh, and M.Y. Yahya, Jurnal Teknologi, 78(3), pp. 111-116, 2016. 